\title{
Immunocytochemical Analysis of Intermediate Filaments in Human Ependymal Tumors
}

\author{
D. Izukawa and B. Lach
}

\begin{abstract}
The peroxidase anti-peroxidase technique was used for localization of glial fibrillary acidic protein (GFAP) and vimentin (VM) in 19 ependymal tumors in order to determine if a unique pattern of intermediate filament (IF) expression could be demonstrated. Cytokeratin (CK) immunoreactivity was examined in a subgroup of 7 tumors with papillary pattern. Nineteen non-ependymal neuroectodermal tumors were used as controls. Ependymomas, subependymomas and astrocytomas were positive for both IF. Oligodendrogliomas, oligodendroglial portions of mixed gliomas and the majority of medulloblastomas were negative for GFAP and VM. Areas of poor differentiation in all tumors demonstrated little expression of any IF. A composite ependymoma/choroid plexus papilloma showed the presence of GFAP, VM and CK in the papillomatous portion only. Four papillary ependymomas were negative for CK. This study emphasizes the parallel distribution of GFAP and VM in well differentiated ependymomas and other glial tumors and casts doubt upon the concept of VM as a marker for de-differentiation in neuroectodermal neoplasia.
\end{abstract}

RÉSUMÉ: Analyse immunocytochimique des filaments interédiaires dans les tumeurs de l'épendyme chez l'homme Nous avons utilisé la technique peroxidase anti-peroxidase pour localiser la protéine gliofibrillaire acide (PGFA) et la vimentine (VM) dans 19 tumeurs de l'ependyme afin de déterminer si nous pouvions mettre en évidence un type particulier d'expression du filament intermédiaire (FI). Nous avons examiné l'immunoréactivité de la cytokératine (CK) dans un sous-groupe de 7 tumeurs présentant une disposition papillaire. Nous avons utilisé dix-neuf tumeurs neuro-ectodermiques comme contrôles. Les épendymomes, les subépendymomes et les astrocytomes étaient positifs pour les deux Fl. Les oligodendrogliomes, les zones oligodendrogliales des gliomes mixtes et la majorité des médulloblastomes étaient négatifs pour la PGFA et la VM. Les zones peu différentiées de toutes les tumeurs présentaient peu ou pas d'expression de Fl. Un papillome composite épendymome/plexus choroïde contenait de la PGFA, de la VM et de la CK seulement dans la zone papillomateuse. Quatre épendymomes étaient négatifs pour la CK. Cette étude souligne la distribution parallèle de la PGFA et de la VM dans les épendymomes bien différentiés et les autres tumeurs gliales et met en doute le concept que la VM est un marqueur de la dédifférentiation dans les néoplasies neuro-ectodermiques.

Can. J. Neurol. Sci. 1988; 15:114-118

Intermediate filaments (IF's) with diameters of 7-11nm. form a major component of the vertebrate cell cytoskeleton. Vimentin (VM) is the first IF protein detectable in immature glia ${ }^{1}$ but is largely replaced by glial fibrillary acidic protein (GFAP) in differentiated astrocytes. Co-expression of VM with GFAP has been shown in mature neuroglia in experimental animals $\mathrm{s}^{2,3}$ and man. ${ }^{4}$ The presence of both IF markers is also well documented in human astrocytomas. $5,6,7,8$

The cytokeratin (CK) proteins form a complex family of polypeptides ranging in molecular weight from 40 to $68 \mathrm{kD}$. A specific pattern of CK components characterizes a given type of epithelium and its corresponding tumors. ${ }^{9} \mathrm{CK}$ has been detected in mature human choroid plexus ${ }^{10.11}$ and in choroid plexus tumors. ${ }^{11,12}$ Mature ependymal cells do not show CK immunoreactivity. ${ }^{10,11}$

GFAP has been demonstrated transiently in embryonic ependyma ${ }^{13}$ but not in mature ependymal lining, despite electronmicroscopic illustration of prominent cytoplasmic IF's. ${ }^{14}$ These filaments likely represent VM as shown immuno-cytochemically in adult rats, ${ }^{2}$, adult mice ${ }^{3}$ and normal human ependyma. ${ }^{7,10}$

These observations prompted us to analyze VM, CK and GFAP localization in human ependymal tumors in an attempt to define a unique pattern of expression in formalin fixed, paraffin embedded material.

From the Department of Surgery, Division of Neurosurgery (Dr. Izukawa); Department of Laboratory Medicine (Neuropathology) (Dr. Lach), Ottawa Civic Hospital and University of Ottawa, Ottawa

Presented at the XXVIth Annual Meeting of the Canadian Association of Neuropathologists, September 25th-27th, 1986, Gull Harbour, Hecla Island, Manitoba, Canada Received September 1, 1987. Accepted December 2, 1987

Reprint requests to: Dr. B. Lach, Department of Laboratory Medicine (Neuropathology), Ottawa Civic Hospital, 1053 Carling Ave., Ottawa, Ontario, Canada KIY 4E9 


\section{Material ANd Methods}

The material included thirty-eight tumors from the files of the Ottawa Civic Hospital, collected between 1972 and 1985. The following tumors were examined: ependymomas (12), subependymomas (6), composite ependymoma/choroid plexus papilloma (1), astrocytomas Grade I to IV (5), oligodendrogliomas (2), mixed astro-oligodendrogliomas (4), medulloblastomas (6), and choroid plexus papilloma and choroid plexus carcinoma (one of each). Tissues were fixed in $10 \%$ buffered formalin and submitted for routine paraffin embedding. Sections were cut at
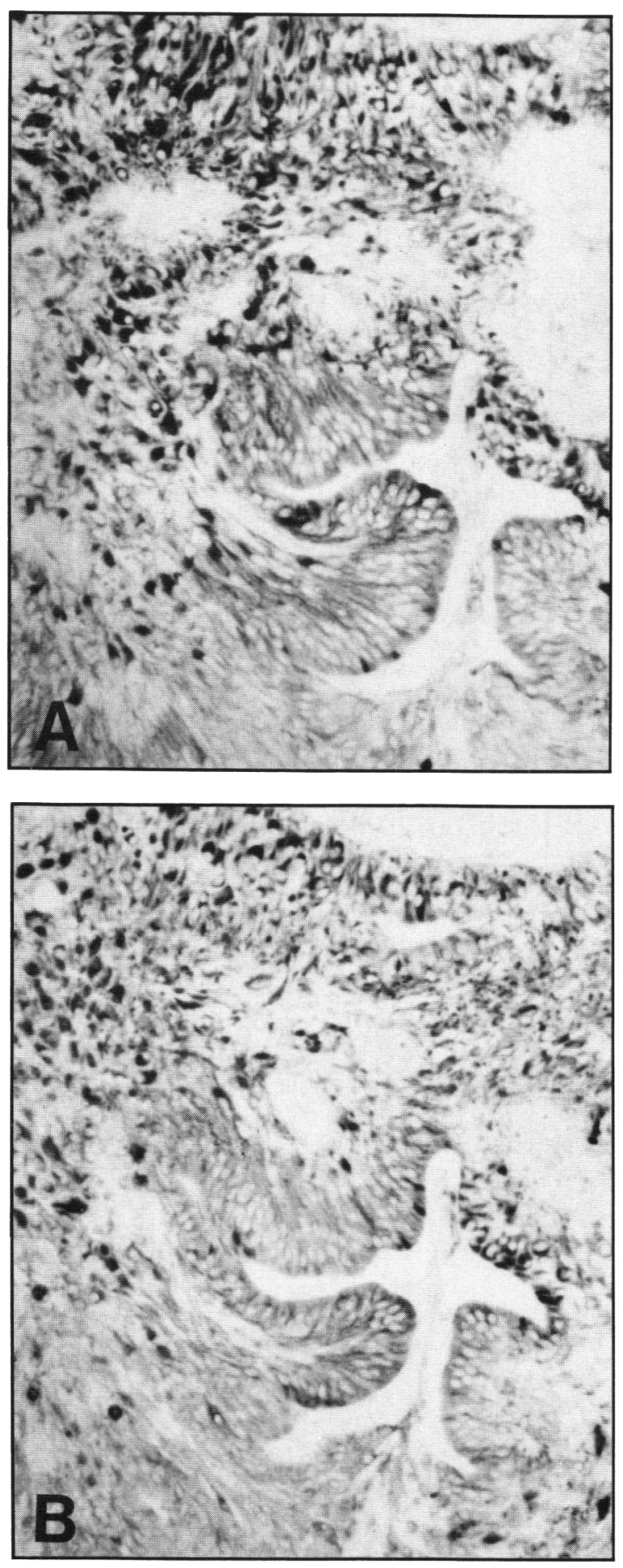

Figure I - Well differentiated ependymoma. Pap for Vimentin $(A)$ and $G F A P(B)$ show very strong reaction in the same population of cells. Magn. $120 \mathrm{X}$.
5 to 6 microns and processed for the peroxidase anti-peroxidase (PAP) method of Sternberger. ${ }^{15}$ The following dilutions of primary antisera were used: 1) Rabbit anti-GFAP (Dako, 1:200); 2) Monoclonal mouse antibodies against GFAP (kindly supplied by Dr. B. Liwnicz, University of Cincinnatti Medical Center, USA, 1:80) - only on ependymomas selected for double immunoreactions; 3) Rabbit anti-VM (Eurodiagnostics, 1:200); 4) Monoclonal mouse anti-CK antibodies (44-64 kD, Lab Systems, 1:100).

The incubation of the first antibody layer was carried out overnight at $40^{\circ} \mathrm{C}$. For polyclonal primary antisera, the second layer consisted of swine anti-rabbit immunoglobulins (Dako, 1:50), applied at $37^{\circ} \mathrm{C}$ for 30 minutes. Subsequent incubation was carried out with PAP complex (1:100) according to the standard method of Sternberger. ${ }^{15}$

For monoclonal antibodies, the Avidin-Biotin-PAP method was used ${ }^{16}$ (commercially available kit from Vector Laboratories, Burlington, $\mathrm{Ca}$., USA).

Double Immunoreactions Six tumors with the strongest PAP reaction for intermediate filaments were examined by combining PAP and alkaline phosphatase immunolabelling on the same section. ${ }^{17,18}$ The first layer of antibodies against either GFAP or VM was followed by the PAP method as described above. Next, rabbit anti-serum against the other intermediate filaments was applied to the same section $\left(40^{\circ} \mathrm{C}\right.$ /overnight) and goat anti-rabbit IgG labelled with alkaline phosphatase (Kappel Laboratories, Malvern, $\mathrm{Pa}$. USA), $\left(37^{\circ} \mathrm{C} / 45\right.$ minutes), was utilized as the second marker. Control sections for double reactions consisted of serially cut slides "immunostained" by either PAP or alkaline phosphatase method alone. Double immunostaining was carried out with various combinations of antibodies and color reactions developed as the first and second layers. After the first reaction, selected microscopic fields were photographed for color transparencies, marked and rephotographed following the second immunoreaction. Subsequently, color transparencies and tissue sections were analyzed simultaneously.

Ten ependymomas were studied ultrastructurally, primarily for confirmation of diagnosis. The tissue for electronmicroscopy was gluteraldehyde fixed, prepared according to routine method ${ }^{19}$ and examined in the Philips 200 microscope.

\section{RESULTS}

Ependymomas Eleven of twelve ependymomas showed parallel expression of GFAP and VM in tumor cells forming rosettes, perivascular pseudo-rosettes and papillae (Figure la, b). Neither protein was detected in one poorly differentiated ependymoma or in compact, less differentiated cellular areas of the other eleven tumors. The relative proportion of VM-positive and GFAP-positive cells varied from tumor to tumor and could not be correlated with any morphological type of ependymoma. Neither filament protein showed preferential expression in perikarya or processes. Vessel wall elements were consistently VM-positive and GFAP-negative. In one unique case of ependymoma with pleomorphic features, VM was present without GFAP in rounded cells loosely arranged in a myxoid stroma (Figure 2a, b). The same tumor showed both VM and GFAP in foci of spindle-shaped cells and perivascular pseudo-rosettes. Electronmicroscopic examination of the rounded cells confirmed their ependymal nature but revealed very few intermediate filaments (Figure 2c). 
Double labelling confirmed the co-existence of both IF proteins within the majority of tumor cells in all eleven cases. This was most evident in rosettes, pseudo-rosettes and papillary formations. However, separate expression of each filament type was shown by complete dissociation of GFAP reactivity from that of VM in some processes or perikarya.

CK was not detected in any of the ependymomas with a papillary pattern of differentiation.
Subependymomas Expression of VM and GFAP was seen in similar populations of cells in all six tumors. The cells positive for both IF most often show features of small astrocytes. Double immunostaining was not carried out on these neoplasms.

Composite Ependymoma/Choroid Plexus Papilloma One IVth ventricle tumor comprised large areas of choroid plexus papilloma (CPP) while other sections of the same lesion clearly

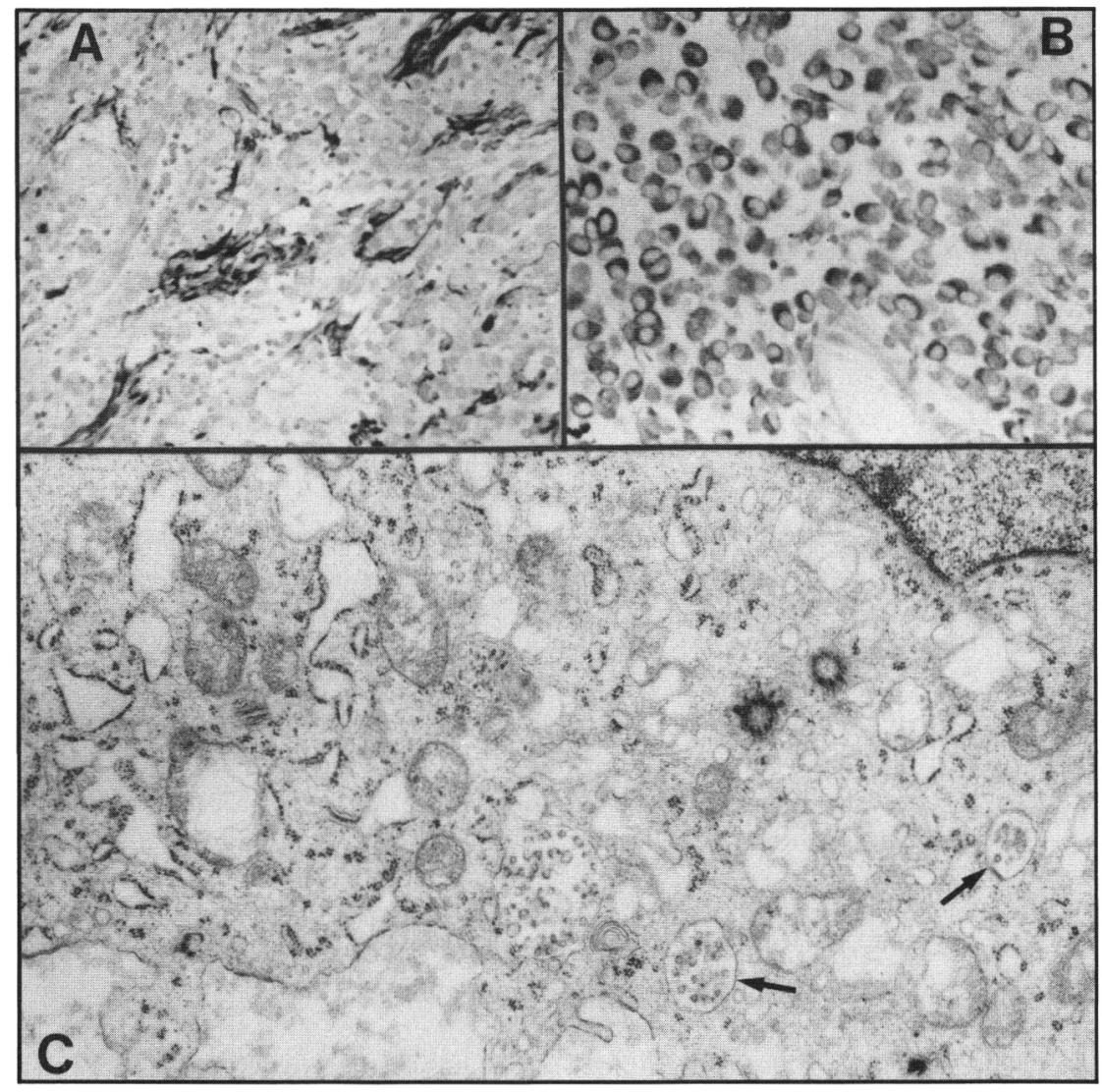

Figure 2-Ependymoma withstrong reactionforVimentin and GFAP in separate cell types. GFAP is positive only in perivascular spindle cells $(A)$, while Vimentin is positive in round cells $(B)$. Magn. $120 X(A), 180 X$ $(B)$. The same rounded cells in electronmicroscopy (C) show well developed RER and a relatively small number of intermediate filaments, considering the intense PAP reaction for Vimentin shown in $(B)$. Abortive cilia (arrows) and basal bodies suggest ependymal differentiation. Magn. $13000 X$.

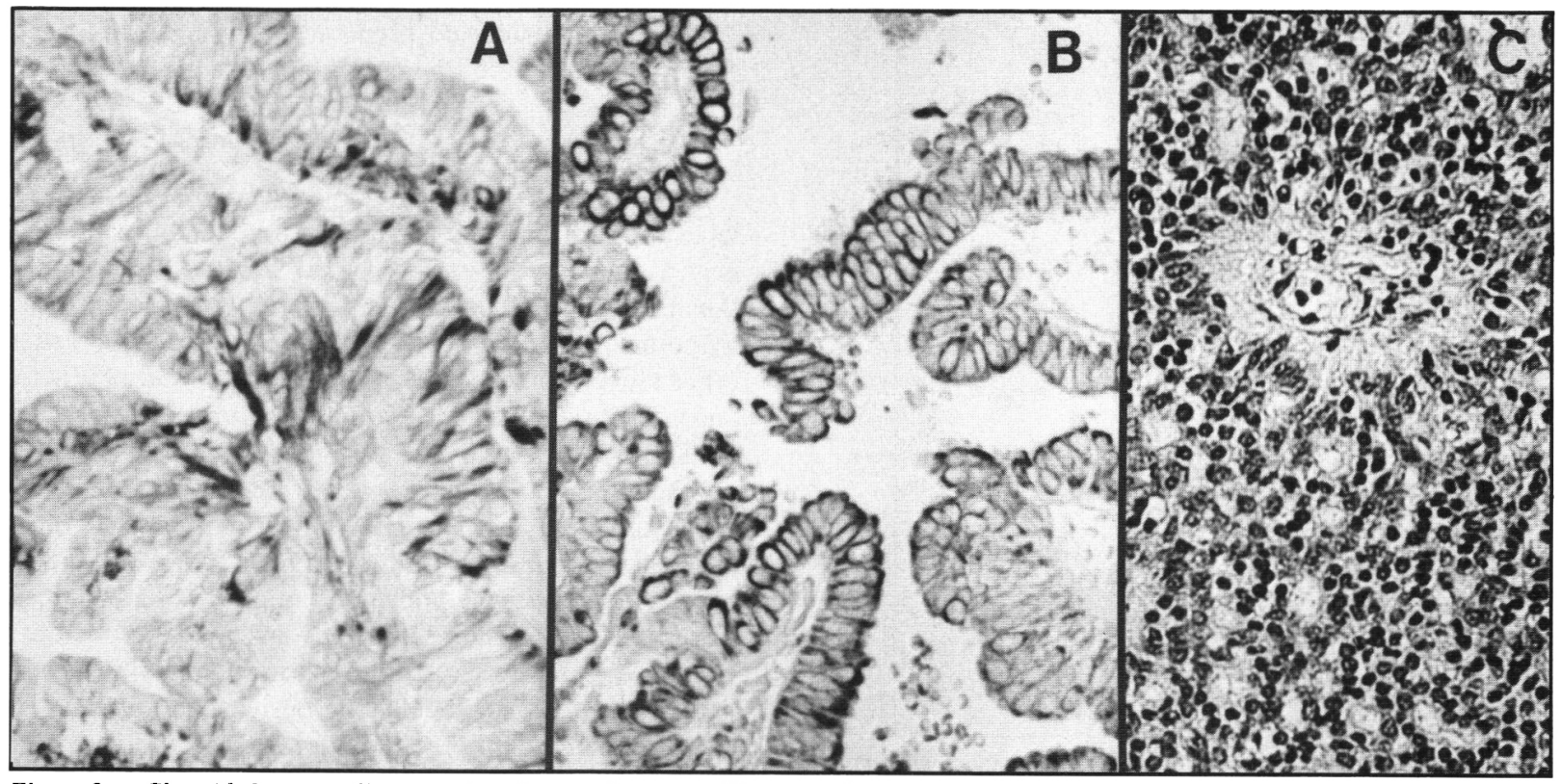

Figure 3 - Choroid plexus papilloma portion of composite tumor with many cells positive for GFAP (A) and cytokeratin (B). Magn.180X.The same tumor in other fields shows features of typical ependymoma $(C)$ negative for examined intermediate filaments (H\&E, Magn. $140 X)$. 
demonstrated ependymal differentiation, confirmed ultrastructurally. The CPP portion showed GFAP, CK and VM in the epithelial cells (Figure 3), and only VM in the connective tissue stroma. Solid ependymal areas of this neoplasm were negative for IF protein.

Control Tumors Well differentiated astrocytomas and astrocytic components of mixed gliomas showed strong reaction for GFAP and VM. Conversely, poorly differentiated areas of these tumors contained very few cells expressing either IF protein. Neither filament was demonstrable in oligodendrogliomas or oligodendroglial portions of mixed tumors. One of six medulloblastomas showed occasional foci of GFAP-positive tumor cells. Almost all neuroepithelial cells of the CPP were strongly positive for $\mathrm{CK}$ while GFAP was present in a few foci. The fibrovascular core of each papilla was VM-positive. Choroid plexus carcinoma showed no reaction with any of the antisera.

\section{Discussion}

Vimentin is the first intermediate filament protein expressed during embryological development regardless of cell type. Except in mesenchymal cells, it is later replaced by IF protein specific for each cell line ${ }^{20}$ During neoplastic transformation, cell type specificity of IF expression is conserved to a large extent (21), forming the basis for immunocytochemical IF protein analysis as a histo-diagnostic tool.

Immunocytochemical techniques have shown the simultaneous presence of both GFAP and VM in human astrocytomas. ${ }^{5,6,7,8}$ Previous analysis of the co-expression of these IF proteins in ependymal tumors has been limited to a small number of cases included in larger series of various neuroectodermal tumors of the central nervous system. ${ }^{6,7.11 .22}$ Duffy and co-workers ${ }^{22}$ described the distribution of GFAP in ten ependymomas. Reaction was most intense in perivascular cells and in "cuboidal" cells forming tubules or cavities. We have confirmed these results and have demonstrated co-expression of $\mathrm{VM}$ in a virtually identical cell population. Our findings in the group of control tumors were in agreement with previous studies $^{6.7}$ and further emphasized the parallel distribution of VM and GFAP in most neuroglial neoplasms.

Based on the finding that VM synthesis precedes that of GFAP during maturation of neuroglia in experimental animals,' some authors have contended that VM may represent a marker for de-differentiation in glial neoplasia. ${ }^{5,6}$ Our results argue against this conclusion in that: 1) Expression of VM and GFAP predominantly in the ependymal cells forming rosettes and pseudo-rosettes, and in the large mature astrocytes, indicates a high degree of correlation between the morphological signs of differentiation of these cell types and expression of both IF antigens. 2) VM was absent from medulloblastomas and de-differentiated cellular areas of ependymomas. 3) VM was present with GFAP in well differentiated slow-growing subependymomas.

Herpers et $a^{8}$ showed preferential localization of VM at juxta-nuclear sites in neoplastic astrocytes, whereas GFAP was found in both perikarya and processes. They cited this finding as evidence for the existence of two distinct IF systems in astroglia. We have not been able to demonstrate analogous distribution of filaments in neoplastic ependymoglia. The close parallel distribution of GFAP and Vimentin in ependymomas suggests an elaborate network of co-existing IF's in cell bodies and processes. This contention is supported by demonstrations of GFAP and VM co-polymerization in single filaments in cultured human glioma cells. ${ }^{24}$ As well, our double immunohistochemical reactions show co-expression of GFAP and VM within many individual ependymocytes. That this phenomenon is not merely an artifact of cross reaction of antisera is confirmed by the complete dissociation of GFAP and VM immunoreactivity in some cells in the same sections.

The ependymoma with a large number of VM-positive rounded cells in a myxoid stroma showed a disproportionately small number of IF's on electronmicroscopic examination, relative to the intensity of the immuno-histochemical reaction for VM. The discrepancy between PAP reactivity and ultrastructural demonstration of IF suggests that a pool of VM-specific protein may be produced prior to assembly of structural VM filaments in neoplastic ependymal cells. Another unusual finding in this ependymoma was the extraordinary richness of rough endoplasmic reticulum. This feature, together with strong VM-reactivity, the presence of a continuous basal lamina around some cells and an abundance of myxoid stroma, may herald an early stage of mesenchymal metaplasia in this tumor, as has been demonstrated in other neuroectodermal neoplasms. ${ }^{25}$ However, previous studies on bone and cartilage formation in glial tumors with ependymal differentiation have indicated that metaplastic transformation arises in the connective tissue stroma ${ }^{26}$ Whether a direct transformation of ependymal cells to mesenchymal cells may take place in human ependymomas is not known. Therefore confirmation of this hypothesis must await further ultrastructural and immunocytochemical studies on ependymomas with a distinct mesenchymal component.

Several authors ${ }^{27.28}$ have suggested that focal GFAP positivity in choroid plexus papilloma (CPP) represents "divergent ependymal differentiation". Certainly the histological and immunocytochemical characteristics of our composite tumor support this concept. This neoplasm demonstrated differentiation along both ependymal and choroid plexus cell lines. A control CPP showed an immunocytochemical profile identical to that of the CPP portion of the composite tumor. An equally plausible explanation for this unique tumor morphology would invoke differentiation towards choroid plexus papilloma in an ependymoma. The lack of CK immuno-reactivity in other papillary ependymomas in our series does not disprove this hypothesis and analysis of CK content in a larger series of such tumors is warranted.

\section{ACKNOWLEDGEMENTS}

The authors wish to extend thanks to Mr. Alistair Gregor and Mrs. Barbara Kosabek-Williams for expert technical assistance, and to Mrs. Elizabeth Lortie for her aid in the preparation of the manuscript.

\section{REFERENCES}

1. Dahl D, Rueger DC, Bignami A. Vimentin, the 57,000 molecular weight protein of fibroblast filaments, is the major cytoskeletal component in immature glia. Europ J Cell Biol 1981; 24: 191-196.

2. Shaw G, Osborne $M$, Weber $K$. An immunofluorescent microscopic study of neurofilament triplet proteins, vimentin and glial fibrillary acidic protein in the adult rat brain. Eur J Cell Biol 1981; 26: 68-82. 
3. Schnitzer J, Franke WW, Schachner M. Immunocytochemical demonstration of vimentin in astrocytes and ependymal cells in developing adult mouse nervous system. J Cell Biol 1981; 90: 435-447.

4. Yen SH, Fields KL. Antibodies to neurofilament, glial filament and fibroblast intermediate filament proteins bind to different cell types of the nervous system. J Cell Biol 1981; 88: 115-126.

5. Roessmann U, Velasco ME, Gambetti P, et al. Vimentin intermediate filaments are increased in human neoplastic astrocytes. $J$ Neuropathol Exp Neurol 1983; 42: 309 (A).

6. Yung WKA, Luna M, Borit A. Vimentin and glial fibrillary acidic protein in human brain tumors. J Neuro-Oncol 1985; 3: 35-38.

7. Schiffer D, Diordana MT, Mauro A, et al. Immunocytochemical demonstration of vimentin in human cerebral tumors. Acta Neuropathol (Berlin) 1986; 70: 209-219.

8. Herpers MJHM, Raemaekers FSC, Aldeweireldt J, et al. Coexpression of glial fibrillary acidic protein and vimentin type intermediate filaments in human astrocytoma. Acta Neuropathol (Berlin) 1986; 70: 333-339.

9. Moll R, Franke WW, Schiller DL, et al. Catalogue of human cytokeratins: patterns of expression in normal epithelia, tumors and cultured cells. Cell 1982; 31: 11-24.

10. Kasper M, Karsten U, Stosiek P. Detection of cytokeratin(s) in epithelium of human plexus choroideus by monoclonal antibodies. Acta Histochem 1986; 78: 101-103.

11. Miettinen M, Clark R, Virtanen I. Intermediate filament proteins in choroid plexus and ependyma and their tumors. Am J Pathol 1986; 123: 231-240.

12. Coffin CM, Wick MR, Braun JT, et al. Choroid plexus neoplasms, clinico-pathological and immunohistochemical studies. Am J Surg Pathol 1986; 10: 394-404.

13. Roessmann U, Velasco ME, Sindely SD, et al. Glial fibrillary acidic protein (GFAP) in ependymal cells during development. An immunocytochemical study. Brain Res 1980; 200: 13-21.

14. Peters A, Palay SL, Webster H de F. The fine structure of the nervous system: The neurons and supporting cells. Saunders (Philadelphia), 1976: 273.

15. Sternberger LA. Immunocytochemistry. Second edition. John Wiley and Sons (New York). 1979.
16. Hsu SM, Raine L, Fanger $H$. Use of avidin-biotin-peroxidase complex $(\mathrm{ABC})$ in immunoperoxidase techniques: A comparison between $A B C$ and unlabelled antibody (PAP) procedures. J Histochem Cytochem 1981; 29: 577-580.

17. Mason DY, Sammons R. Alkaline phosphatase and peroxidase for double immunoenzymatic labelling of cellular constituents. J Clin Pathol 1978; 31: 454-460.

18. Malik NJ, Daymon ME. Improved double immunoenzyme labelling using alkaline phosphatase and horseradish peroxidase. J Clin Pathol 1982; 35: 1092-1094.

19. McDowell EM. Fixation and processing. In: Diagnostic Electronmicroscopy. V.1, B.J. Trump and R.T. Jones, eds., Wiley Medical Publications, New York, Toronto, 1978: 113-140.

20. Bonnin JM, Rubinstein LJ. Immunohistochemistry of central nervous system tumors. J Neurosurg 1984; 60: 1121-1133.

21. Osborn M, Weber K. Biology of disease: Tumor diagnosis by intermediate filament typing: A novel tool for surgical pathology. Lab Invest 1983; 48: 372-394.

22. Duffy PE, Graf L, Huang YY, et al. Glial fibrillary acidic protein in ependymomas and other brain tumors. J Neurol Sci 1979; 40: 133-146.

23. Deck JH, Eng LF, Bigbee J, et al. The role of glial fibrillary acidic protein in the diagnosis of central nervous system tumors. Acta Neuropathol (Berlin) 1978; 42: 183-190.

24. Sharp G, Osborne M, Weber K. Occurrence of two different intermediate filament proteins in the same filament in situ within human glioma cell lines. Exp Cell Res 1982; 144: 385-395.

25. Kepes JJ, Rubinstein, Chiang H. The role of astrocytes in the formation of cartilage in astrocytomas: An immunohistochemical study of four cases. Am J Pathol 1984; 117: 471-483.

26. Mathews T, Moossy J. Gliomas containing bone and cartilage. J Neuropathol Exp Neurol 1974; 33: 456-471.

27. Rubinstein LJ, Brucher JM. Focal ependymal differentiation in choroid plexus papillomas. An immunoperoxidase study. Acta Neuropathol (Berlin) 1981; 53: 29-33.

28. Taratuto AL, Molina $\mathrm{H}$, Monges J. Choroid plexus tumors in infancy and childhood. Focal ependymal differentiation. Acta Neuropathol (Berlin) 1983; 59: 304-308. 